\title{
ANALISIS PENYEBAB TERJADINYA SELISIH ANGGARAN PENJUALAN PADA KOPERASI KARYAWAN CV. ANANDA PUTRI PALEMBANG
}

\author{
Oktariansyah *)
}

\begin{abstract}
ABSTRAK
Tujuan dari penelitian ini untuk mengetahui penyebab terjadinya selisih anggaran dan realisasi penjualan pada Koperasi Karyawan CV. Ananda Putri Palembang. Metode analisis yang digunakan adalah metode analisis kualitatif. Penelitian ini sebagai masukan mengenai apa yang menjadi penyebab terjadinya selisih anggaran dan realisasi penjualan khususnya pada unit toko dan unit Elmebes. Hasil penelitian menunjukkan bahwa penyebab utama dari adanya selisih anggaran dan realisasi penjualan pada unit toko dan elmebes yaitu kurangnya variasi produk yang ditawarkan pada unit toko. Banyaknya pesaing yang menawarkan jumlah produk yang lengkap dan harga yang bersaing juga kualitas yang baik menyebabkan konsumen banyak melakukan pembelian pada pesaing koperasi. Persaingan juga terjadi pada merk dagang yang ditawarkan koperasi seringkali tidak sesuai dengan keinginan pelanggan koperasi.
\end{abstract}

\section{Kata Kunci : Selisih anggaran dan realisasi penjualan}

\section{A. Latar Belakang}

Perusahaan pada umumnya didirikan bertujuan untuk mendapatkan laba dan berkembang menjadi besar, dengan menggunakan sumber-sumber ekonomi yang dimiliki oleh perusahaan. Manajemen perlu menetapkan strategi dan kebijaksanaan yang efektif dan efisien, sehingga perusahaan dapat berjalan secara berdaya guna dan berhasil guna untuk mencapai tujuan perusahaan tersebut.

Berdasarkan keadaan tersebut maka manajemen perusahaan dituntut untuk rnemiliki dan meningkatkan kemampuannya dalam melaksanakan kegiatankegiatan yang menyangkut penentuan program perusahaan di masa depan serta penjabarannya menjadi suatu rencana yang realistis, sederhana, kuantitif, dan terperinci. Untuk mencapai tujuan, perusahaan mernerlukan manajemen yang baik,yang dapat melaksanakan fungsi manajemen dengan sebaik-baiknya agar dapat bekerja efektif dan efisien.

Perencanaan dan pengendalian atas penjualan dilakukan dengan sasaran mencapai target penjualan yang diinginkan sehingga manajemen dapat memperkirakan laba yang akan diperoleh dalam satu periode. Perusahaan akan menerapkan perencanaan dan pengendalian atas kegiatan tersebut untuk mendapatkan hasil yang diharapkan dari penjualan dengan cara menetapkan suatu anggaran.

Menurut Hansen dan Mowen yang dialih bahasa oleh Anccela $A$. Hermawan (2009 : 718) faktor-faktor yang mempengaruhi penjualan dapat di kelompokkan menjadi faktor internal dan eksternal. Faktor internal terdiri dari penjualan tahun lalu, kebijaksanaan penjualan yang diterapkan, tenaga kerja yang dimiliki dan modal yang tersedia. Sedangkan faktor eksternal yaitu pesaing, tingkat penghasilan masyarakat dan faktor geografis suatu daerah tersebut merupakan faktor-faktor yang dapat menyebabakan terjadinya selisih (variance) antara anggaran penjualan yang disusun oleh perusahaan dengan realisasi penjualan yang terjadi. Selisih tersebut dapat berupa selisih yang rnenguntungkan maupun selisih yang dapat merugikan perusahaan.

*) Dosen Tetap Fakultas Ekonomi UPGRI Palembang 
Anggaran merupakan suatu perencanaan perusahaan, yang disusun dengan teliti serta meliputi tahap operasi dari perusahaan dalam jangka waktu tertentu dimasa yang akan datang. Anggaran sebagai alat pengendalian sebagai ukuran atas pelaksanaan pekerjaan, apakah rencana yang telah disusun dapat direalisasikan kemudian dari hasil pengukuran tersebut dapat dilakukan koreksi. Perencanaan dan pengendalian merupakan dua faktor yang sangat penting yang bersifat menunjang dan berhubungan dalam aktivitas badan pengurus dalam menjalankan tugasnya.

Penerapan fungsi perencanaan dan pengendalian merupakan aktivitas yang berhubungan dengan penilaian atau evaluasi mengenai apa saja yang telah dicapai, setidaknya perusahaan dipandang perlu apakah perusahaan telah bekerja secara efektif dan efisien agar tercapai tujuan yang telah ditetapkan. Pada prosesnya anggaran harus terorganisir dengan rapi, jelas dan komprehensif, serta penyusunannya harus dilakukan dengan hati-hati dan tidak dilakukan secara emosional. Nilai yang muncul pada suatu anggaran harus disesuaikan dengan hasil yang diperoleh sebelumnya dan juga dapat disesuaikan untuk kemungkinan perubahan pada volume penjualan dan produksi berikutnya.

Dalam proses realisasi anggaran dan realisasi penjualan tidak begitu jauh dari yang sudah dianggarkan. Dalam hal ini diperlukan evaluasi dan analisa perhitungan komprehensif terhadap hasil anggaran tersebut, karena tujuan akhir dari suatu anggaran adalah memaksimalkan seluruh unit yang ada pada perusahaan yang idealnya dapat meminimalkan biaya yang harus dikeluarkan dan memaksimalkan laba. \begin{tabular}{llr}
\multicolumn{2}{c}{ Anggaran juga dapat } \\
dirumuskan sebagai & $\begin{array}{r}\text { dindakan } \\
\text { pengaturan }\end{array}$ dan pengendalian
\end{tabular} pelaksanaan supaya tujuan dapat dicapai secara efektif den efisien. Dalam kaitan dengan realisasi anggaran penjualan, dapat dijadikan sebagai standar atau tolak ukur bagi perusahaan untuk menilai dan membandingkan apakah pelaksanaan anggaran penjualan tersebut telah tercapai atau menyimpang dari yang telah ditetapkan.

Rencana penjualan yang memadai harus mempertimbangkan banyak kemungkinan dan alternatif yang tersedia serta tnemperhitungkan faktor-faktor yang mempengaruhinya. Melalui perencanaan penjualan tersebut diharapkan target penjualan dapat tercapai dan berpengaruh terhadap pembentukan laba secara maksimal.

Koperasi Karyawan CV. Ananda Putri Palembang, bergerak dibidang usaha toko, simpan pinjam, perkreditan, serta pengadaaan dan penyaluran kebutuhan sembilan bahan pokok dan kebutuhan sehari-hari. Dalam melakukan kegiatannya Koperasi Karyawan CV. Ananda Putri Palembang selalu melakukan pembuatan rencana anggaran pendapatan dan belanja setiap tahunnya. Rencana anggaran pendapatan dan belanja ini berfungsi sebagai pedoman dan memberikan arah serta sekaligus memberikan target-terget yang harus dicapai oleh koperasi di waktu yang akan datang.

$$
\text { Adapun masalah yang }
$$
dihadapi oleh Koperasi Karyawan CV. Ananda Putri Palembang yaitu adanya selisih antara anggaran dan realisasi penjualan khususnya yang terjadi pada bidang usaha unit toko dan Elmebes (elektronika, mebel,HP, dan lain-lain). Pada bidang usaha unit toko barang yang dijual 
yaitu berupa barang konsinyasi dan barang kebutuhan sehari-hari. Sedangkan pada unit Elmebes barang yang dijual yaitu berupa alat-alat elektronik, Mebel, HP, Sepeda dan lain-lain. Selisih ini dapat menguntungkan maupun merugikan koperasi. Namun demikian selama tiga tahun terakhir ini yaitu pada tahun 2010, 2011, dan 2012 terdapat selisih anggaran dan realisasi penjualan yang merugikan koperasi, sehingga mengakibatkan terjadinya penurunan pendapatan koperasi khususnya bidang usaha toko dan Elmebes dari tahun 2010 sampai dengan 2012.

\section{B. Rumusan Masalah}

Berdasarkan uraian diatas maka rumusan masalah yang akan dibahas oleh penulis adalah "Apakah yang menyebabkan terjadinya selisih anggaran dan realisasi penjualan pada Koperasi Karyawan CV. Ananda Putri Palembang.

\section{Metode Penelitian}

Menurut Sugiyono (2009:60), variabel penelitian pada dasarnya adalah segala sesuatu yang berbentuk apa saja yang ditetapkan oleh peneliti untuk dipelajari sehingga diperoleh informasi tentang hal tersebut, kemudian ditarik kesimpulannya.

Di dalam penelitian ini variabel yang digunakan adalah variabel tunggal karena sifatnya hanya mendeskripsikan saja, tidak ada uji korelasi atau mencari pengaruh. sehingga tidak diperlukan adanya variabel bebas dan variabel terikat. Maka yang menjadi variabel penelitiannya adalah anggaran penjualan pada Koperasi Karyawan CV. Ananda Putri Palembang.

\section{Populasi dan Sampel}

Dalam melaksanakan penelitian ini, peneliti terlebih dahulu akan menjelaskan mengenai populasi dan sampel yang akan diteliti sehimgga dapat diperoleh keputusan apakah penelitian ini memerlukan sampel atau tidak dan bagaimana cara pengambilan sampel tersebut.

Menurut Sugiyono ( 2009:80) populasi adalah wilayah generalisasi yang terdiri dari atas objek/subjek yang mempunyai kualitas dan karakteristik tertentu yang diterapkan oleh peneliti untuk dipelajari dan kemudian ditarik kesimpulannya.

Berdasarkan pengertian diatas, populasi dapat diartikan sebagai wilayah generalisasi dari kesimpulan penelitian. Dalam penelitian ini populasi yang peneliti pakai adalah anggaran dan realisasi penjualan pada Koperasi Karyawan CV. Ananda Putri Palembang dari tahun 1990 sampai dengan 2013.

Sedangkan menurut Sugiyono (2009:81) sampel adalah bagian dari jumlah dan karakteristik yang dimiliki oleh populasi tersebut. Apa yang dipelajari dari sampel itu, kesimpulannya akan diberlakukan untuk populasi.

Dalam penelitian ini yang menjadi sampel penelitian adalah anggaran dan realisasi dari tahun 2010 sampai dengan 2012 pada Koperasi Karyawan CV. Ananda Putri Palembang.

\section{E. Teknik Pengumpulan Data}

Teknik pengumpulan data yang digunakan dalam penelitian adalah wawancara dan dokumentasi wawancara dilakukan dengan tanya jawab langsung dengan bagian penjualan pada Koperasi Karyawan CV. Ananda Putri Palembang. Dokumentasi dilakukan dengan cara mengambil data yang ada berupa 
anggaran dan realisasi penjualan pada Koperasi Karyawan CV. Ananda Putri Palembang

\section{F. Teknik Analisis Data}

Menurut Iqbal Hasan (2009:244) ada dua metode analisis data yang digunakan untuk menganalisis data yaitu :

\section{Analisis Kualitatif}

Adalah analisis data dimana datanya tidak dinyatakan dalam bentuk angka-angka.

2. Analisis Kuantitatif

Adalah analisis data dimana datanya dinyatakan dalam bentuk bilangan angka yang dapat diukur.

Analisis data yang digunakan dalam penelitian ini adalah metode kualitatif.

\section{G. PEMBAHASAN}

Berdasarkan hasil pengumpulan data dan wawancara yang penulis lakukan pada Koperasi Karyawan CV. Ananda Putri Palembang selama lebih kurang satu bulan yakni pada bulan Agustus sampai dengan bulan September 2013 serta pengamatan penulis sendiri baik secara langsung maupun tidak langsung, maka penulis akan melakukan analisis mengenai penyebab dari adanya selisih anggaran dan realisasi penjualan pada Koperasi Koperasi Karyawan CV. Ananda Putri Palembang. Terdapat beberapa faktor penyebab terjadinya selisih anggaran dan realisasi penjualan pada Koperasi Karyawan CV. Ananda Putri Palembang antara lain sebagai berikut :

\section{Faktor Internal}

Faktor internal merupakan faktor penyebab terjadinya selisih antara anggaran dan realisasi penjualan yang bersumber dari dalam perusahaan. Faktor internal perusahaan yang akan dianalisis meliputi penjualan tahun lalu dan kebijakan perusahaan.

\section{a) Penjualan Tahun Lalu}

Koperasi Karyawan CV. Ananda

Putri Palembang dalam menyusun anggaran penjualan menggunakan penjualan tahun sebelumnya sebagai pedoman penyusunan anggaran.

1) Tahun 2010 penjualan pada unit Toko sebesar Rp.105.216.438, sedangkan penjualan pada unit Elmebes sebesar Rp. 585.741.705.

2) Tahun 2011 penjualan pada unit Toko sebesar Rp.77.734.317, sedangkan penjualan pada unit Elmebes sebesar Rp.355.317.500.

3) Tahun 2012 penjualan pada unit Toko sebesar Rp.57.828.000, sedangkan penjualan pada unit Elmebes sebesar Rp.315.305.000.

Dari uraian diatas dapat diketahui bahwa penjualan pada unit toko dan elmebes tahun 2010 dan 2011 mengalami peningkatan. Namun pada tahun 2012 penjualan pada kedua unit tersebut mengalami penurunan yang cukup tinggi yang menyebabkan penurunan pendapatan pada kedua unit tersebut.

Berdasarkan hasil wawancara penulis dengan bagian penjualan terjadinya penurunan penjualan pada unit toko dan elmebes tahun 2012 disebabkan variasi jenis barang yang ditawarkan kurang, sehingga berdampak pada kurangnya daya beli anggota pada unit toko, sedangkan pada unit elmebes penurunan penjualan lebih disebabkan karena anggota koperasi lebih banyak memilih kredit alternatif berupa kredit simpan pinjam sehingga dapat di belanjakan sesuai keinginan atau kebutuhan anggota. Tingkat bunga pada unit simpan pinjam lebih rendah dari kredit elmebes. Tingkat bunga simpan pinjam yaitu $1 \%$ per bulan atau $12 \%$ per tahun, sedangkan pada unit 
Elmebes tingkat bun;anya $1.5 \%$ per bulan atau $18 \%$ per tahun.

Pada penjualan tahun lalu yang akan dianalisis meliputi kualitas, kuantitas, kebijakan harga dan daerah penjualan.

\section{(a) Kualitas}

Kualitas produk merupakan hal yang perlu mendapat perhatian yang utama dari perusahaan, mengingat suatu produk berkaitan erat dengan masalah kepuasan konsumen yang merupakan tujuan dari kegiatan pemasaran yang dilakukan perusahaan. Setiap perusahaan harus memiliki tingkat kualitas yang membantu atau menunjang usaha untuk meningkatkan atau mempertahankan posisi produk di dalam pasar sasarannya.

Pada unit elmebes kualitas barang yang ditawarkan kualitas terjamin. Pada unit toko barang yang ditawarkan memiliki kualitas yang terjamin namun oleh karena sering terjadi kekosongan barang pada unit ini, maka menyebabkan pelanggan koperasi beralih ke tempat lain yang menjadi pesaing Koperasi Karyawan CV. Ananda Putri Palembang.

\section{(b) Kuantitas}

Kuantitas produk berpengaruh terhadap masalah kepuasan konsumen yang merupakan tujuan akhir suatu perusahaan. Tingkat iumlah produk yang ditawarkan perusahaan erat kaitannya dengan kualitas barang yang dibeli. Apabila pelanggan merasa puas tentunya akan membeli kembali produk tersebut dan secara tidak langsung dapat meningkatkan jumlah atau kuantitas barang yang dijual seiring meningkatnya barang yang diminta oleh pelanggan. Sebaliknya produk yang ditawarkan kurang memuaskan pelanggan, maka pelanggan akan berpindah ke produk lain yang berpengaruh terhadap kuantitas barang yang dijual.

Koperasi Karyawan CV. Ananda Putri Palembang dalam menyediakan produk pada unit toko dilakukan dengan penyetokan barang. Namun poduk yang ditawarkan pada unit toko kurang bervariasi dan menurut hasil wawancara penulis kepada penjaga toko, banyak pelanggan yang tidak mendapatkan barang yang diinginkan pada unit toko. Seringkali jenis barang yang ditawarkan ada tetapi merk yang diinginkan oleh pelanggan tidak sesuai dengan yang dijual oleh unit toko Koperasi Karyawan CV. Ananda Putri Palembang. Hal inilah yang sering menjadi penyebab berkurangnya daya beli masyarakat pada unit toko dan menyebabkan pendapatan pada unit toko mengalami penurunan.

Pada unit Elmebes dalam menyediakan produk dilakukan dengan pemesanan produk pada pihak ketiga dalam hal ini terdapat kerjasama antara koperasi dengan perusahaan lain dalam penyediaan barang. Namun adakalanya pemesanan tersebut tidak dapat terpenuhi dan berakibat pada persediaan produk yang dijuai pada Koperasi Karyawan CV. Ananda Putri Palembang belum memadai dan membutuhkan waktu yang cukup lama dalam memenuhi permintaan pelanggan.

\section{(c) Kebijaksanaan harga}

Kebijakan harga merupakan suatu kebijaksanaan yang diterapkan suatu perusahaan yang berhubungan dengan tingkat harga yang diberikan pada suatu produk. Kebijaksanaan penetapan harga jual produk sangat penting karena harga merupakan bagian penawaran suatu produk. Harga satuan produk merupakan 
penentu bagi permintaan pasar. Harga juga mempengaruhi posisi pesaing perusahaan dan juga mempengaruhi market sharenya. Harga jual produk bagi perusahaan akan memberikan hasil dengan menciptakan sejumlah pendapatan dan keuntungan bersih Penetapan harga jual selain memperhatikan fisik produk dan pesaing dari perusahaan lain juga dipengaruhi saluran distribusi penjualan.

Harga jual produk pada Koperasi Karyawan CV. Ananda Putri Palembang bervariasi tergantung pada jumlah produk yang dijual. Harga yang ditawarkan pada unit toko relatif sama dengan yang ditawarkan oleh pesaing. Namun jenis barang yang ditawarkan kurang bervariasi Hai ini lah yang sering menjadi kendala bagi koperasi untuk memperoleh pemasukan. Pelanggan koperasi seringkali melakukan pembelian pada pesaing koperasi dikarenakan barang yang diinginkan pelanggan tidak dapat dipenuhi oleh koperasi juga harga yang ditawarkan pesaing tidak terlalu jauh perbedaannya dari harga yang ditawarkan oleh koperasi Palas.

Produk yang dijual pada Koperasi Karyawan CV. Ananda Putri Palembang pada unit toko meliputi barang kebutuhan pokok sehari-hari dalam hal ini sembako. Sedangkan pada unit Elmebes barang yang dijual berupa alat elektonik, sepeda, mebel, $\mathrm{Hp}$, dan lain-lain. Pada unit elmebes harga yang ditawarkan cukup bervariasi namun minat pelanggan koperasi khususnya anggota koperasi dalam melakukan pembelian masih kurang. Anggota koperasi lebih banyak menyukai kredit simpan pinjam dibandingkan dengan kredit pada unit elmebes.

\section{(d) Daerah penjualan}

Penentuan daerah penjualan harus terlebih dahulu mengetahui potensi penjulaan dan ruang lingkup daerah penjualan. Adapun penjualan produk yang dijual oleh Koperasi Karyawan Palas yang terletak di jalan Sultan Mahmud Badaruddin II Palembang. Daerah penjualan pada Koperasi Karyawan CV. Ananda Putri Palembang cukup strategis. Pada mulanya tidak banyak yang menjadi pesaing koperasi, namun seiring dengan perkembangan waktu saat ini ada banyak pesaing yang menjual barang serupa dengan koperasi yang letaknya berdekatan dengan koperasi.

\section{b) Kebijakan Perusahaan \\ 1) Promosi}

Promosi merupakan salah satu sarana untuk memperkenalkan produk kepada pelanggan. Apalagi dengan adanya produk yang baru, maka masyarakat belum mengetahui produk tersebut, sehingga dirasakan perlu adanya melakukan promosi. Kegiatan promosi yang dilakukan oleh Koperasi Karyawan CV. Ananda Putri Palembang melalui pameran, brosur, dan juga spanduk, dengan tujuan dapat memberikan informasi mengenai produk yang ditawarkan pada tujuan akhirnya pelanggan akan membeli produk tersebut.

Pada unit elmebes Koperasi Karyawan CV. Ananda Putri Palembang memberikan hadiah tambahan khususnya produk elektronik dan mebel, misalnya pada pembelian mebel koperasi memberikan hadiah berupa tempat payung dan lain- lain. Hal ini dilakukan untuk mendcrong konsumen agar lebih meningkatkan volume pembelian khususnya pada unit elmebes. 


\section{2) Pemilihan Saluran Distribusi}

Pemilihan saluran distribusi penjualan merupakan saluran yang digunakan oleh produsen untuk menyalurkan produk kepada konsumen, saluran distribusi penjualan merupakan struktur yang menggambarkan alternatif saluran distribusi yang dipilih. Pemilihan saluran distribusi penjualan yang digunakan pada Koperasi Karyawan CV. Ananda Putri Palembang pada unit toko dan unit elmebes terdapat perbedaan. Pada unit toko Koperasi melakukan penyetokan barang dengan melakukan pemesanan barang kepada agen yang menyediakan barang tersebut. Kemudian barang tersebut dijual kepada konsumen dan anggota koperasi. Pada unit elmebes dalam menyalurkan barang ke anggota koperasi dilakukan dengan kerjasama pengadaan barang dengan pihak ketiga. Dalam hal ini anggota mengajukan permohonan kredit terhadap barang yang akan di beli, kemudian koperasi melakukan pencatatan dengan formulir yang ada yang diisi oleh anggota koperasi. Apabila anggota koperasi yang mengajukan kredit elmebes menyetujui jumlah kredit yang harus dibayar tiap bulannya, barulah koperasi menunjuk satu perusahaan dagang yang menyediakan barang yang diinginkan anggota. Setelah adanya kesepakatan antara koperasi dengan anggota kemudian barang disalurkan ke anggota dengan mengantar barang tersebut ke alamat dari anggota yang mengajukan kredit Elmebes.

\section{Faktor Eksternal}

$\begin{array}{lrr}\text { Faktor } & \text { eksternal } & \text { perusahaan } \\ \text { adalah } & \text { faktor-faktor } & \text { yang }\end{array}$
mempengaruhi realisasi penjualan dan merupakan penyebab terjadinya selisih antara anggaran dan realisasi penjualan pada Koperasi Karyawan
CV. Ananda Putri Palembang. Faktor eksternal tersebut yaitu pesaing dan penghasilan masyarakat, keadaan perekonomian dan teknologi.

\section{a) Persaingan}

Pesaing merupakan faktor yang paling dominan yang dihadapi oleh perusahaan karena faktor ini dapat mempengaruhi perkembangan perusahaan untuk dapat bertahan hidup dalam dunia bisnis, atas dasar itu manajemen perusahaan harus lebih unggul dalam membuat atau menciptakan strategi maupun inovasiinovasi yang lebih baik diharapkan dapat menghadapi persaingan. Letak koperasi yang cukup dekat dengan pesaing koperasi menyebabkan persaingan penjualan produk pada unit toko. Persaingan harga dan kuantitas barang juga sering terjadi. Adakalanya pesaing koperasi menawarkan barang dengan harga relatif murah dan lebih lengkap dari yang ditawarkan Koperasi Karyawan CV. Ananda Putri Palembang, sehingga menyebabkan banyak pelanggan lebih memilih berbelanja ke tempat lain.

Berdasarkan wawancara dengan hagian penjualan khususnya pada unit toko dan elmebes diketahui bahwa yang menjadi pesaing pada Koperasi Karyawan CV. Ananda Putri Palembang yaitu toko Marina, Toko Abi, Toko Ahong, Toko Setia Baru yang dikelola oleh Koperasi Nurul Amal yang memiliki mini market yang letaknya dekat dengan Koperasi Karyawan CV. Ananda Putri Palembang yang kuantitas produknya lebih banyak ditawarkan dan juga menawarkan harga yang relatif murah dibandingkan dengan Koperasi Karyawan CV. Ananda Putri Palembang. 


\section{b) Penghasilan Anggota Koperasi}

Faktor eksternal yang paling penting yaitu penghasilan anggota Koperasi Karyawan CV. Ananda Putri Palembang. Jumlah anggota Koperasi per 31 Desember 2010 berjumlah 934 orang. Anggota koperasi terdiri dari Karyawan tetap, karyawan kontrak dan pegawai Koperasi Karyawan CV. Ananda Putri Palembang. Tingkat penghasilan anggota Koperasi Karyawan CV. Ananda Putri Palembang bervariasi sesuai dengan status anggota yang tercatat pada bagian SDM Penghasilan anggota koperasi yang berstatus karyawan sesuai dengan tingkat golongan karyawan.

$$
\text { Tingkat golongan Koperasi }
$$

Karyawan CV. Ananda Putri Palembang terdiri dari tingkat biasa, menengah, utama dan pembina. Berdasarkan data yang terdapat pada Koperasi Karyawan CV. Ananda Putri Palembang jumlah anggota koperasi yang berstatus karyawan CV. Ananda Putri Palembang sebanyak 768 orang, karyawan kontrak 131 orang dan pegawai koperasi berjumlah 35 orang. Tingkat golongan karyawan yang menjadi anggota Koperasi Karyawan CV. Ananda Putri Palembang yaitu tingkat biasa berjumlah 515 orang, tingkat menengah berjumlah 200 orang dan tingkat utama berjumlah 53 orang.

Dari data di atas dapat dilihat bahwa mayoritas anggota koperasi berstatus karyawan CV. Ananda Putri Palembang dan kebanyakan berasal dari golongan karyawan tingkat biasa. Berdasarkan data yang didapatkan penulis bahwa jumlah penghasilan dari karyawan tingkat bisa berkisar antara 2 juta rupiah hingga 4 juta rupiah. Pada golongan karyawan tingkat biasa ini kebanyakan berasal dari karyawan baru yang memiliki masa kerja kurang dari lima tahun yang memiliki penghasilan antara 2 juta hingga 3 juta rupiah.

Pada dasarnya tingkat pendapatan dari karyawan CV. Ananda Putri Palembang memang tidak memiliki masalah, pendapatan yang ada memungkinkan Koperasi Karyawan CV. Ananda Putri Palembang yang menjadi anggota Koperasi Karyawan CV. Ananda Putri Palembang untuk melakukan pembelian pada unit toko dan elmebes. Namun berdasarkan hasil wawancara penulis dengan petugas koperasi bahwa adanya penurunan pendapatan pada kedua unit ini disebabkan oleh kurangnya minat dari anggota untuk melakukan pembelian. Hal ini disebabkan oleh seringkali tidak tersedianya barang yang diinginkan pelanggan khususnya pada unit toko juga adanya pesaing baik dilingkungan sekitar tempat koperasi berada ataupun pesaing yang berada di luar lingkungan koperasi.

\section{c) Keadaan Perekonomian}

Tingkat pertumbuhan Indonesia yang tidak teratur seperti nilai tukar rupiah terhadap dolar yang turut menentukan harga jual per satuan unit produk terutama produk elektronik. Sehingga minat konsumen untuk membeli alat elektronik berkurang karena harga yang relatif mahal. Selain itu faktor yang mempengaruhi pertumbuhan perekonomian Indonesia pernah mengalami krisis ekonomi, terjadinya inflasi dimana harga barang secara keseluruhan menjadi meningkat dan berdampak kepada turunnya minat beli masyarakat.

Pertumbuhan ekonomi sering terjadi dari tahun ketahun, sehingga pasar tidak stabil dan sering menjadi masalah bagi masyarakat dan para pengusaha. Pertumbuhan ekonomi merupakan salah satu faktor yang 
menyebabkan adanya selisih anggaran penjualan dan realisasi penjualan pada Koperasi Karyawan CV. Ananda Putri Palembang. Kurangnya minat konsumen untuk membeli barang kebutuhan dikarenakan kurangnya penghasilan dan biaya-biaya yang meningkat. Faktor ini sangat meresahakan masyarakat karena dengan pertumbuhan ekonomi masyarakat akan mengalami kesulitan dalam melakukan apapun dan perusahaan akan kekurangan pelanggan.

\section{d) Teknologi}

Kemajuan teknologi juga mempengaruhi tingkat penjualan, dimana semakin tinggi tingkat kecanggihan produk elektronik yang ada maka jenis elektronik yang lama yang tingkat kecanggihannya dibawah produk elektronik yang baru akan ditinggalkan.

\section{F. Kesimpulan dan Saran \\ 1. Kesimpulan}

Berdasarkan pembahasan dan uraian yang telah dijelaskan pada sebelumnya, maka penulis akan menarik kesimpulan sehubungan dengan hal-hal yang dibahas, kemudian penulis akan mencoba memberi saran-saran yang mungkin bermanfaat bagi Koperasi Karyawan CV. Ananda Putri Palembang. Adapun kesimpulan yang dapat penulis ambil yaitu faktor-faktor penyebab terjadinya selisih anggaran penjualan dengan realisasi penjualan yaitu :

a) Faktor Internal

Faktor internal perusahaan
merupakan faktor penyebab
terjadinya selisih anggaran dan
realisasi penjualan yang bersumber
dari dalam perusahaan. Faktor
internal terdiri dari:

1) Penjualan tahun lalu

Pada penjualan tahun lalu yang sangat berpengaruh pada tingkat penjualan yaitu adanya kuantitas barang yang ditawarkan sedikit dan tidak bervariasi. Sering terjadinya kekosongan barang menjadi kendala besar bagi koperasi untuk mencapai target penjualan yang telah dianggarkan.

2) Kebijaksanaan perusahaan

Promosi yang dilakukan perusahaan yaitu melalui melalui pameran, brosur, dan juga spanduk, dengan tujuan dapat memberikan informasi mengenai produk yang ditawarkan. Kegiatan promosi yang dilakukan sudah cukup baik, pemilihan saluran distribusi juga baik namun kondisi unit toko yang kurang lengkap jenis barang dagangannya kurang menarik minat anggota untuk melakukan pembelian.

b) Faktor Eksternal

Faktor eksternal perusahaan merupakan faktor penyebab terjadinya selisih anggaran dan realisasi penjualan yang bersumber dari luar perusahaan. Faktor eksternal terdiri dari :

1) Persaingan

Perusahaan dagang yang menjadi pesaing Koperasi Karyawan CV. Ananda Putri Palembang pada unit toko dan elmebes cukup banyak. Pesaing pada Koperasi Karyawan CV. Ananda Putri Palembang menyediakan barang dagangan yang cukup bervariasi dan lengkap. Letak dari para pesaing itu sendiri tidak terlalu jauh dari tempat berdirinya Koperasi Karyawan CV. Ananda Putri Palembang. 
2) Penghasilan Anggota Koperasi

Penghasilan anggota koperasi yang beraneka ragam sangat berpengaruh pada kegiatan pembelian barang yang dilakukan anggota koperasi. Adanya perbedaan status antara karyawan dengan pegawai kontrak juga adanya perbedaan golongan karyawan yang berakibat pada perbedaan upah antara pegawai biasa, madya, utama dan pembina juga cukup berpangaruh terhadap daya beli anggota koperasi.

3) Keadaan Perekonomian

Tingkat pertumbuhan Indonesia yang tidak teratur seperti nilai tukar rupiah terhadap dolar yang turut menentukan harga jual per satuan unit produk terutama produk elektronik. Sehingga minat konsumen untuk membeli alat elektronik berkurang karena harga yang relatif mahal. Kurangnya minat konsumen untuk membeli barang kebutuhan dikarenakan kurangnya penghasilan dan biaya-biaya yang meningkat.

4) Teknologi

Kemajuan teknologi juga mempengaruhi tingkat penjualan, dimana semakin tinggi tingkat kecanggihan produk elektronik yang ada maka jenis elektronik yang lama yang tingkat kecanggihannya dibawah produk elektronik yang baru akan ditinggalkan. Ketidakpuasan pelanggan akan pelayanan dari koperasi juga menjadi salah satu penyebab menurunnya pendapatan pada Koperasi Karyawan CV. Ananda Putri Palembang. Jumlah barang yang ditawarkan pada Koperasi Karyawan CV. Ananda Putri Palembang kurang memenuhi selera masyarakat khususnya anggota koperasi.

\section{Saran}

Dari kesimpulan yang dikemukakan diatas, penulis akan mencoba memberikan saran-saran yang kiranya dapat bermanfaat bagi Koperasi Karyawan CV. Ananda Putri Palembang, seperti :

1. Jenis barang yang ditawarkan khususnya pada unit toko lebih diperbanyak lagi dengan memperhatikan selera konsumen dan juga anggota koperasi.

2. Pemilihan perusahaan yang menjadi rekanan dalam penyediaan barang lebih diteliti lagi, apakah perusahaan tersebut dalam penyediaan barang ke konsumen dapat memenuhi keinginan dan selera dari konsumen dan anggota koperasi.

3. Dalam menghadapi persaingan terutama pada penjualan unit toko hendaknya memperhatikan keinginan konsumen terutama pada kualitas barang dagang dan lebih menperhatikan akan keinginan konsumen.

4. Pada unit elmebes lebih diperhatikan lagi teknologi yang berkembang saat ini dengan tujuan akhir dapat memenuhi keinginan dan selera konsumen dan anggota koperasi akan elektonik, sepeda, handphone, dan barang lain yang ditawarkan pada unit elmebes.

\section{DAFTAR PUSTAKA}

Didit Herlianto, 2011. Teknik Penyusunan Operasional Anggaran Penerbit : Gosyen Publishing, Yogyakarta.

Don.R.Hansen, Mayyaanne M. Mowen.2009. Akuntansi 
Manajemen , Buku 2.. Penerbit Salemba Empat Jakarta.

Drs. M. Munandar, 2010. Budgeting Perencanaan Kerja Pengkoordinasian Kerja Pengawasan Kerja. Yogyakarta.

Fakultas Ekonomi Universitas PGRI Palembang 2013. Pedoman Penulisan Skrpsi. Universitas PGRI Palembang : Palembang.

Gunawan Adisaputro dan Marwan Asri. $2009 . \quad$ Anggaran Perusahaan, Edisi kedua, BPFE UGM, Yogyakarta.

Mulyadi, 2009. Akuntansi Manajemen. Penerbit Salemba Jakarta.

Republik Indonesia. Undang-Undang Koperasi No. 17 Tahun 2012 : Jakarta.

Sari Wirda. 2009. Analisis Anggaran dan Realisasi Penjualan Alat-alat Listrik Pada PD. Genna Teknik Palembang (Tidak dipublikasikan)

Sugiyono, 2009. Metodologi Penelitian Kuantitatif, Kualitatif dan $R \& D$, Penerbit : Alfabeta, Bandung 
